Tyas Nyonita Punjungsari, 2017. Pengaruh Molase Terhadap Aktivitas

Konsorsium Bakteri Pereduksi Sulfat Dalam Mereduksi Sulfat $\left(\mathrm{SO}_{4}^{-}\right)$. Journal Viabel Pertanian. (2017),11(2) 39-49

\title{
PENGARUH MOLASE TERHADAP AKTIVITAS KONSORSIUM BAKTERI PEREDUKSI SULFAT DALAM MEREDUKSI SULFAT $\left(\mathrm{SO}_{4}^{-}\right)$
}

\author{
Tyas Nyonita Punjungsari ${ }^{1)}$
}

1) Dosen prodi Agroteknologi, Fakultas Pertanian, Universitas Islam Balitar

\begin{abstract}
The purpose of this research is to understanding the effect of organic matter on BPS activity in reducing sulfate. Research carried out in batch culture using erlenmeyer, and using a completely randomized design (CRD). The treatment given is organic matter amounted to $308 \mathrm{mg} / \mathrm{L}, 617 \mathrm{mg} / \mathrm{L}$ and $1.234 \mathrm{mg} / \mathrm{L}$ and control. Each treatment was repeated 3 times. The parameters observed in this study is SO4 concentration. Using Duncan New Multiple Range Test (DNMRT) at 5\% level for data analysis. The results showed that the molecular concentration of $617 \mathrm{mg} / \mathrm{L}$ was able to decrease the sulfate concentration at the fastest, then consecutively the concentration of molasses $1.234 \mathrm{mg}$ / $L$, and control. Based on the Anova test the significant value is less than 0.05. Thus it can be stated that there is an effect of addition molasses to decrease sulfate concentration by sulfate reducing bacteria consortium.
\end{abstract}

Keywords: Molasses, Sulfate Reducing Bacteria Consortium (SRB), Sulfate (SO4-).

\section{PENDAHULUAN}

Air asam tambang adalah limbah cair yang banyak mengandung logam dan sulfat. Air asam tambang terbentuk pada saat mineral bereaksi dengan oksigen dan air ketika dilakukan aktivitas pertambangan. Air asam tambang dapat mengakibatkan stress (kerusakan) lingkungan yang berbahaya, seperti pengasaman dan pencemaran logam pada ekosistem air (Hesketh et al., 2010).

Pengolahan limbah asam tambang yang memiliki kandungan sulfate tinggi dapat dilakukan dengan mengunakan agen biologis berupa konsorsium bakteri yang mampu mereduksi sulfat. Menurut Purnamaningsih, (2016) Bakteri Pereduksi Sulfat (BPS) dari kotoran kambing memiliki aktivitas yang optimal dalam mereduksi sulfat dan mengendapkan logam Mn dengan skala batch culture.

Toleransi BPS terhadap konsentrasi logam berat dan sulfat yang tinggi dapat ditingkatkan dengan metode imobilisasi menggunakan zeolit alam. Peningkatan toleransi BPS terhadap konsentrasi logam berat dan sulfat yang tinggi selain dengan teknik imobilisasi dengan menggunakan zeolit, juga dapat dengan pemilihan bahan organik yang tepat untuk pertumbuhan BPS. Menurut Mosaa et al. (2002) bahan organik digunakan oleh BPS sebagai donor elektron. Pemilihan donor elektron akan berpengaruh terhadap kecepatan reduksi sulfat (Cao et al., 2012). Donor elektron pada BPS biasanya berupa senyawa organik dengan berat molekul yang rendah seperti asam organik (laktat, piruvat, 
format dan asetat) atau alkohol (ethanol, propanol) sebagai sumber karbon (Rzecycka and Blaszcyck, 2005).

Bahan organik seperti asam organik atau alkohol yang telah siap digunakan memiliki nilai ekonomi yang tinggi. Alternatif dalam mengatasinya dapat dengan menggunakan bahan yang bernilai ekonomi rendah namun mampu menyediakan sumber karbon yang baik untuk mikroorganisme salah satunya adalah molase atau sering disebut dengan tetes tebu (produk samping dari industri pengolahan gula tebu).

Pemanfaatan molase sebagai alternatif bahan organik dalam optimalisasi kerja BPS dalam mereduksi konsentrasi sulfat tinggi belum pernah dilakukan. Oleh karena itu, perlu dilakukan penelitian mengenai pengaruh molase terhadap aktivitas konsorsium bakteri pereduksi sulfat pada reduksi konsentrasi sulfat.

\section{TINJAUAN PUSTAKA}

\section{Sifat Senyawa Sulfat}

Sulfat (SO42-) merupakan salah satu senyawa sulfur. Jenis senyawa sulfur alamiah berdasarkan tingkat oksidasi dalam siklus sulfurnya ada empat jenis yaitu senyawa sulfida (S2-), sulfur elemental (S0), sulfat (SO42-), dan sulfur organik (C-SH) (Lens et.al., 2004). Sulfat (SO42-) merupakan kombinasi sulfur (S) dan oksigen (O) secara alami sulfat terdapat pada tanah dan bantuan. Pada area pertambangan sulfur berikatan dengan mineralmineral lain (Moncur et al., 2009) seperti tertera pada Tabel 1.

Tabel 1. Senyawa sulfur yang ditemukan pada area pertambangan

\begin{tabular}{ll}
\hline Mineral & $\mathrm{Rumus}$ kimia \\
\hline Pyrrhotite & $\mathrm{Fe}(1-\mathrm{x}) \mathrm{S}$ \\
Galena & $\mathrm{PbS}$ \\
Sphalerite & $(\mathrm{Zn}(1-\mathrm{x}), \mathrm{Fex}) \mathrm{S}$ \\
Sphalerite & $\mathrm{Cu}_{5} \mathrm{FeS}{ }_{4}$ \\
Pentlandite & $(\mathrm{Fe}, \mathrm{Ni})_{9} \mathrm{~S}_{8}$ \\
Arsenopyrite & $\mathrm{FeAsS}$ \\
Marcasite & $\mathrm{FeS}_{2}$ \\
Pyrite & $\mathrm{FeS}_{2}$ \\
Chalcopyrite & $\mathrm{CuFeS}_{2}$ \\
Magnetite & $\mathrm{Fe}^{2+} \mathrm{Fe}^{3+}{ }_{2} \mathrm{O}_{4}$ \\
Molybdenite & $\mathrm{MoS}_{2}$ \\
\hline
\end{tabular}

Limbah cair yang mengandung sulfat berasal dari industri yang menggunakan asam sulfat atau senyawa sulfat lain (Bratkova et al., 2011) seperti pembakaran. fosil, pertambangan, kertas dan tekstil. Asam sulfat secara umum digunakan sebagai pengatur pH selama proses produksi, oleh karena itu sulfat biasanya ditemukan pada limbah cair (Liamleam and Annachhatre, 2007). Selain proses industri, sulfat juga dapat berasal dari proses oksidasi senyawa sulfur sebagai contoh oksidasi sulfur pada air asam tambang (Liamleam and Annachhatre, 2007). 
Sulfat dapat menurunkan $\mathrm{pH}$ air secara drastis serta meningkatkan kelarutan logam berat (Havlin et al., 1999). pH air yang rendah dapat membunuh ikan dan organisme akuatik lain. Selain itu sulfat dapat menurunkan $\mathrm{pH}$ tanah sehingga akan menghambat pertumbuhan tanaman (Fahrudin, 2009)

\section{Sifat Bakteri Pereduksi Sulfat}

Bakteri yang mampu menggunakan sulfat sebagai akseptor elektron terakhirnya dikenal sebagai bakteri pereduksi sulfat. Bakteri pereduksi sulfat memanfaatkan sulfat (SO42-), tiosulfat (S2O32-) dan sulfit (SO32-) sebagai akseptor elektron terminal dalam respirasi metabolismenya, yang kemudian direduksi menjadi sulfida. Menurut fahrudin 2010 berdasarkan penggunaan sulfat bakteri pereduksi sulfat dibedakan menjadi dua yaitu kelompok assimilatory sulfate reduction dan dissimilatory sulfate reduction. Kelompok mikrobia assimilatory sulfate reduction mereduksi sejumlah kecil sulfat untuk mensintesis kopartmen sel yang mengandung sulfur, sedangkan dan dissimilatory sulfate reduction menggunakan sulfat untuk mendapatkan energi.

Disamping itu, untuk memenuhi kebutuhan hidupnya, bakteri pereduksi sulfat juga memerlukan susbtrat organik - umumnya asam organik rantai pendek - seperti asam laktat dan piruvat, yang dihasilkan oleh aktivitas fermentasi bakteri anaerob lainnya. Bakteri pereduksi sulfat merupakan organisme heterotrof anaerob. Sampai saat ini telah dikenal lebih dari 10 genus bakteri pereduksi sulfat. Bakteri pereduksi sulfat yang dikenal dan ditemukan secara luas di alam antara lain adalah Desulfovibrio dan Desulfotomaculum (Moodie dan Ingledew, 1991).

Berdasarkan cara penguraian asam organik, bakteri pereduksi sulfat dikelompokkan menjadi dua kelompok (Kleikemper et al., 2002). Kelompok pertama mengoksidasi senyawa donor secara tidak sempurna, dan menghasilkan senyawa asetat. Kelompok Desulfotomaculum yang membentuk spora dan Desulvofibrio yang tidak membentuk spora merupakan bakteri yang mengoksidasi senyawa organik secara tidak sempurna. Kelompok kedua mampu tumbuh menggunakan alkohol, asetat, asam lemak berbobot molekul tinggi, dan benzoat, seperti Desulfotomaculum acetoxidans, Desulfobacter, Desulfococcus, Desulfosacrina dan Desulfonema (Detmers et al ., 2001). Beberapa spesies dan genus bakteri anaerob dapat bertahan sementara dengan adanya oksigen, namun membutuhkan lingkungan anaerob (tanpa oksigen) untuk pertumbuhannya.

Beberapa faktor pertumbuhan yang berpengaruh terhadap pertumbuhan BPS adalah (Fahruddin, 2010), Suhu: merupakan salah satu faktor pertumbuhan yang sangat berpengaruh pada pertumbuhan mikrobia. Penentuan suhu yang tepat sangat penting dalam efektifitas penerapan BPS di dalam bioreaktor. BPS memilik toleransi suhu yang cukup luas yaitu $20-50 \mathrm{oC}$; $\mathrm{pH}$, pertumbuhan $\mathrm{BPS}$ mempunyai kisaran $\mathrm{pH}$ yang luas, namun aktifitasnya tidak sama pada setiap kondisi $\mathrm{pH}$. Kelompok mikrobia ini dapat tumbuh pada kisaran $\mathrm{pH}$ 3-9; Ion logam berat, BPS memiliki kemampuan untuk mengoksidasi berbagai macam logam berat seperti $\mathrm{Cu}, \mathrm{Zn}, \mathrm{Mn}, \mathrm{Cd}$ dan $\mathrm{Pb}$. 


\section{Karakter Molase}

Molase (tetes tebu) merupakan hasil samping dari industri pengolahan gula yang masih mengandung gula yang cukup tinggi. Kandungan gula molase terutama sukrosa berkisar 48 - 55\% (Prescott \& Dunn, 1959). Menurut Eksi dan Artik (1984) molase mengandung glukosa dan galaktosa 50-80 \%, beberapa mineral seperti fosfor, kalsium, potasium dan asam organik. Kandungan dalam molase kompleks dan heterogen, serta bervariasi berdasarkan pada jenis tebu yang digunakan (tanah, iklim, periode kultur), proses produksi dan efisiensi operasi di pabrik (Castro, 1993). Berdasarkan kandungannya dapat dikatakan bahwa molase merupakan karbohidrat alternatif yang baik untuk nutrisi manusia (Dogan, 2011).

Selain sebagai alternatif sumber nutrisi untuk manusia, molase juga memiliki peranan yang baik pada bidang bioremidiasi. Dalam sekala laboratorium peningkatan kinerja bioagent dalam proses bioremidiasi dapat menggunakan bahan organik dengan berat molekul rendah seperti hidrogen, methanol, ethanol asetat, laktat, propionat, butirat, gula (Cao et al., 2012). Namun dalam skala industri atau dalam penerapannnya dilingkungan bahan organik ini tidak dapat digunakan karena biaya yang dikeluarkan sangat tinggi, penggunaan molase merupakan alternatif sumber energi karbon yang ekonomis untuk optimalisasi proses bioremidiasi oleh mikroorganisme (Somasundaram dan Philip, 2011).

Menurut Michailidesa et al., (2014), biofilter menggunakan molase sebagai sumber karbon organik dapat memberikan solusi yang efektif terhadap masalah pencemaran lingkungan yang serius, karena biayanya yang murah.

Molase juga dapat digunakan sebagai bioagen dalam mengurangi kontaminasi logam berat. Menurut Chen et al., (2015) molase efektif dalam proses bioremidiasi logam karena biaya ekonominya yang rendah, meningkatkan proses reduksi kimia, dan sebagai sumber gula untuk meningkatkan metabolisme mikrobia.

\section{METODE PENELITIAN}

Penelitian ini dilakukan dalam beberapa tahap, antara lain optimasi substrat untuk pengujian aktivitas konsorsium bakteri pereduksi sulfat, pengujian aktivitas konsorsium bakteri pereduksi sulfat dalam sekala batch culture, pengumpulan data dan analisis data.

\section{Sterilisasi}

Peralatan yang terbuat dari gelas dan media tumbuh disterilisasi menggunakan autoclave pada suhu $121 \mathrm{oC}$ selama 20 menit. Peralatan yang mudah rusak oleh panas disterilisasi dengan menggunakan alkhohol $70 \%$.

\section{Persiapan media}

Media yang digunakan untuk menumbuhkan dan kultivasi adalah Media Postgate B (Postgate, 1984) yang disederhanakan. Komposisi media postgate B yang disederhanakan tertera pada Tabel 2. 
Tyas Nyonita Punjungsari, 2017. Pengaruh Molase Terhadap Aktivitas

Konsorsium Bakteri Pereduksi Sulfat Dalam Mereduksi Sulfat $\left(\mathrm{SO}_{4}^{-}\right)$. Journal Viabel Pertanian. (2017),11(2) 39-49

Tabel 2. Komposisi media Postgate B dan limbah sintetik (Janyasuthiwong et al., 2015).

\begin{tabular}{|c|c|c|c|}
\hline Nama Senyawa & Rumus Kimia & $\begin{array}{c}\text { Potgate } \\
(\mathrm{g} / \mathrm{L})\end{array}$ & $\begin{array}{c}\text { Limbah } \\
\text { Sintetik }(g / L)\end{array}$ \\
\hline Natrium asetat & $\mathrm{NaC}_{2} \mathrm{H}_{3} \mathrm{O}_{2}$ & 0 & - \\
\hline Magnesium sulfat & $\mathrm{MgSO}_{4}$ & 1,0 & - \\
\hline Ammonium klorida & $\mathrm{NH}_{4} \mathrm{CL}$ & 0,5 & - \\
\hline Kalium dihidrogen fosfat & $\mathrm{KH}_{2} \mathrm{PO}_{4}$ & 1,0 & - \\
\hline Besi sulfat & $\mathrm{FeSO}_{4}$ & 0,1 & - \\
\hline Asam askorbat & $\mathrm{C}_{6} \mathrm{H}_{8} \mathrm{O}_{6}$ & 0 & - \\
\hline Glukosa & $\mathrm{C}_{6} \mathrm{H}_{12} \mathrm{O}_{6}$ & 0 & - \\
\hline Kalsium klorida & $\mathrm{CaCl}_{2}$ & 0,1 & - \\
\hline Natrium sulfat & $\mathrm{Na}_{2} \mathrm{SO}_{4}$ & 0,5 & 0,1479 \\
\hline Ekstrak yeast & & 0,1 & - \\
\hline Tembaga sulfat & $\mathrm{CuSO}_{4} .5 \mathrm{H}_{2} \mathrm{O}$ & - & 3,929 \\
\hline
\end{tabular}

pH media diatur pada nilai $\mathrm{pH} 4$ dengan penambahan asam sulfat sebelum media disterilisasi (Yusron dkk., 2009).

\section{Sampel konsorsium BPS}

Konsorsium bakteri pereduksi sulfat didapatkan dari kotoran kambing dari limbah peternakan kambing etawa Dusun Kemirikebo, Desa Girikerto, Kabupaten Sleman, Daerah Istimewa Yogyakarta. Sampel kotoran diambil menggunakan sekop. Sampel kemudian dimasukkan ke dalam botol selai dan ditutup rapat.

Sebanyak 10 gram kotoran kambing dimasukkan ke dalam labu erlemeyer ukuran $500 \mathrm{~mL}$, yang sebelumnya telah diberi media potgate B yang disederhanakan, kemudian di seal menggunakan karet dan diinkubasi pada kondisi gelap pada temperatur $30 \mathrm{oC}$ selama 15 hari. Setelah itu, $250 \mathrm{ml}$ suspensi sel pada labu erlenmeyer diambil untuk dibuat subkultur dengan memasukkan kedalam $500 \mathrm{ml}$ labu erlemeyer baru yang telah berisi media dan diinkubasi seperti dalam kondisi sebelumnya. Prosedur ini diulangi setiap 3 minggu untuk menjaga kualitas kultur BPS. BPS yang tumbuh ditandai dengan pembentukan endapan berwarna hitam (ferrous iron) yang muncul beberapa hari setelah diinokulasi (Teclu, 2008).

\section{Kultivasi BPS}

Kultur BPS dikultivasi pada media Postgate B yang disederhanakan $(500 \mathrm{ml})$ dalam $1 \mathrm{~L}$ botol kaca bening (botol bensin). Sebelumnya media disterilisasi terlebih dahulu pada $121 \mathrm{oC}$ selama 20 menit. Setelah selesai media didinginkan pada suhu ruangan. 50 persen inokulum ditambahkan pada media Postgate yang disederhanakan. Botol ditutup dengan cepat untuk memberikan kondisi anaerob. Bakteri pereduksi sulfat diinkubasi pada 30oC selama 24 jam dalam kondisi gelap. Pembentukan Ferosulfida ditandai dengan endapan berwarna hitam mengindikasikan bakteri tumbuh. Botol disimpan pada suhu $30 \mathrm{oC}$ (Carbera et al., 2006). 
Tyas Nyonita Punjungsari, 2017. Pengaruh Molase Terhadap Aktivitas

Konsorsium Bakteri Pereduksi Sulfat Dalam Mereduksi Sulfat $\left(\mathrm{SO}_{4}^{-}\right)$. Journal Viabel Pertanian. (2017),11(2) 39-49

\section{Pembuatan larutan stok Molase}

Molase sebanyak $0,50 \mathrm{ml}, 1,00 \mathrm{ml}$ dan $2 \mathrm{ml}$ dipindahkan pada erlemeyer yang berisi $\mathrm{dH} 2 \mathrm{O}$ sebanyak $1 \mathrm{~L}$ dengan menggunakan pipet ukur. Dalam setiap dosis diambil masing $100 \mathrm{ml}$ dari setiap larutan stok untuk $1 \mathrm{~L}$ larutan sehingga konsentrasi akhir masingmasing dosis sebesar $308 \mathrm{mg} / \mathrm{L}, 617 \mathrm{mg} / \mathrm{L}$ dan $1.234 \mathrm{mg} / \mathrm{L}$ (Chen et al., 2016).

\section{Batch Culture}

Penelitian secara batch culture dilakukan menggunakan botol kaca bening dengan ukuran $1 \mathrm{~L}$. Konsorsium bakteri sebanyak $350 \mathrm{ml}$ diinokulasi pada $350 \mathrm{ml}$ media postgate B yang telah disterilkan. Dalam media postgate konsentrasi sulfat sebanyak $100 \mathrm{ppm}$ dan $\mathrm{Cu}$ sebesar $25 \mathrm{mg} / \mathrm{L}$ (Janyasuthiwong et al., 2015). Dalam media ditambahkan bahan organik berupa molase dengan dosis, $308 \mathrm{mg} / \mathrm{L}, 617 \mathrm{mg} / \mathrm{L}$ dan $1.234 \mathrm{mg} / \mathrm{L}$ (Chen et al., 2016). Kemudian diinkubasi dengan kondisi anaerob pada temperatur $30 \mathrm{oC}$ dalam keadaan gelap. Percobaan dilakukan dengan tiga kali ulangan. Secara berkala dilakukan pengukuran parameter pengamatan pada hari ke $0,1,3,7$, dan 14 .

Parameter yang dilakukan pengujian pada percobaan secara batch culture adalah konsentrasi sulfat $\left(\mathrm{SO}_{4}{ }^{-}\right)$. Pengujian konsentrasi sulfat dilakukan dengan menggunakan larutan buffer sulfat A dengan komposisi $30 \mathrm{~g} / \mathrm{L}$ magnesium klorida heksahidrat, $5 \mathrm{~g} / \mathrm{L}$ natrium asetat trihidrat, $1 \mathrm{~g} / \mathrm{L}$ kalium nitrat, $20 \mathrm{ml} / \mathrm{L}$ asam asetat. Larutan buffer sulfat $\mathrm{B}$ digunakan ketika konsetrasi sulfat kurang dari 5 ppm. Sampel yang akan diuji diambil 100 ml ditambahkan $20 \mathrm{ml}$ larutan buffer sulfat A kemudian dihomogenkan dengan cara digojog, kemudian ditambahkan kristal $\mathrm{BaCl} 2.2 \mathrm{H} 2 \mathrm{O}$ dan diaduk selama 1 menit, dan didiamkan selama 3 menit. Selanjutnya sampel yang sudah siap dianalisis konsentrasi sulfatnya dengan menggunakan spektrofotometer UV-Vis pada panjang gelombang 420 nm.

\section{Analisis Data}

Penelitian dilaksanakan secara batch culture dan continous culture dengan menggunakan bioreaktor secara RAL (Rancangan Acak Lengkap) dengan pemberian dosis zeolit pada limbah sebesar $308 \mathrm{mg} / \mathrm{L}, 617 \mathrm{mg} / \mathrm{L}, 1.234 \mathrm{mg} / \mathrm{L}$ dan kontrol. Setiap perlakuan diulang sebanyak 3 kali. Data yang diperoleh dianalisis secara statistik dengan menggunakan Anova, jika terdapat perbedaan yang nyata dilanjutkan dengan uji Duncan New Multiple Range Test (DNMRT) pada taraf 5\%.

\section{HASIL PENELITIAN DAN PEMBAHASAN}

Indikator yang diamati dalam metode batch culture konsorsium Bakteri Pereduksi Sulfat adalah perubahan warna dan konsentrasi sulfat. Perubahan warna pada batch culture mengindikasikan adanya pertumbuhan bakteri pereduksi sulfat.

Pada batch culture terlihat adanya perubahan yang semakin lama masa inkubasi warnanya semakin gelap. Ketika hari ke 0 warna batch culture masih sangat terang khususnya pada konsentrasi molase 0 , dan $308 \mathrm{mg} / \mathrm{L}$, sedangkan untuk konsentrasi molase $617 \mathrm{mg} / \mathrm{L}$ berwarna lebih gelap, dan untuk konsentrasi molase terbesar $(1.234 \mathrm{mg} / \mathrm{L})$ berwarna sangat gelap, perubahan warna yang terjadi pada hari ke 0 terbentuk karena 
Tyas Nyonita Punjungsari, 2017. Pengaruh Molase Terhadap Aktivitas

Konsorsium Bakteri Pereduksi Sulfat Dalam Mereduksi Sulfat $\left(\mathrm{SO}_{4}^{-}\right)$. Journal

Viabel Pertanian. (2017),11(2) 39-49

sumber konsorsium yang digunakan juga menunjukkan adanya perbedaan warna berdasarkan konsentrasi molase yang digunakan, dapat diamati pada Gambar 1.

Selain perbedaan warna yang terjadi pada hari ke 0 , terdapat perubahan warna per periode waktu yang berbeda, dimana semakin lama waktu inkubasi semakin gelap warna media cair dalam batch culture, warna tergelap ditunjukkan oleh media cair dengan konsentrasi molase $1.234 \mathrm{mg} / \mathrm{L}$, dan semakin kecil konsentrasi molase warna yang dihasilkan juga menjadi semakin lebih terang seperti disajikan pada tabel 3 .

Perubahan warna yang semakin gelap menunjukkan adanya aktivitas bakteri pereduksi sulfat dalam batch culture. Hasil ini didukung oleh pernyataan dari Muyzer and Stam (2008) yang menyatakan bahwa bakteri pereduksi sulfat pada batch culture menggunakan sulfat sebagai penerima elektron terakir untuk mendegradasi senyawa organik yang akan menghasilkan gas Sulfida (H2S) dan ion bikarbonat (HCO3-), dimana $\mathrm{H} 2 \mathrm{~S}$ yang dihasilkan merupakan presipitat yang berwarna hitam, sehingga keberadaannya dapat dijadikan karakteristik adanya kelompok bakteri pereduksi sulfat.

Semakin besar konsentrasi molase semakin hitam pula keadaan media cair dalam batch culture, hal ini dapat mengindikasikan bahwa semakin besar konsentrasi molase yang digunakan, maka bahan organik yang tersedia pun semakin banyak untuk mikrobia. Bahan organik yang cukup akan menunjang pertumbuhan mikrobia dalam batch culture, karena mikrobia menggunakannya sebagai sumber energy dan donor elektron melalui aktivitas oksidasi dari bahan organik tersebut. Pernyataan ini didukung oleh Lens et al. (1998) yang menyatakan bahwa bakteri pereduksi sulfat membutuhkan elektron dari aktivitas oksidasi bahan organik.
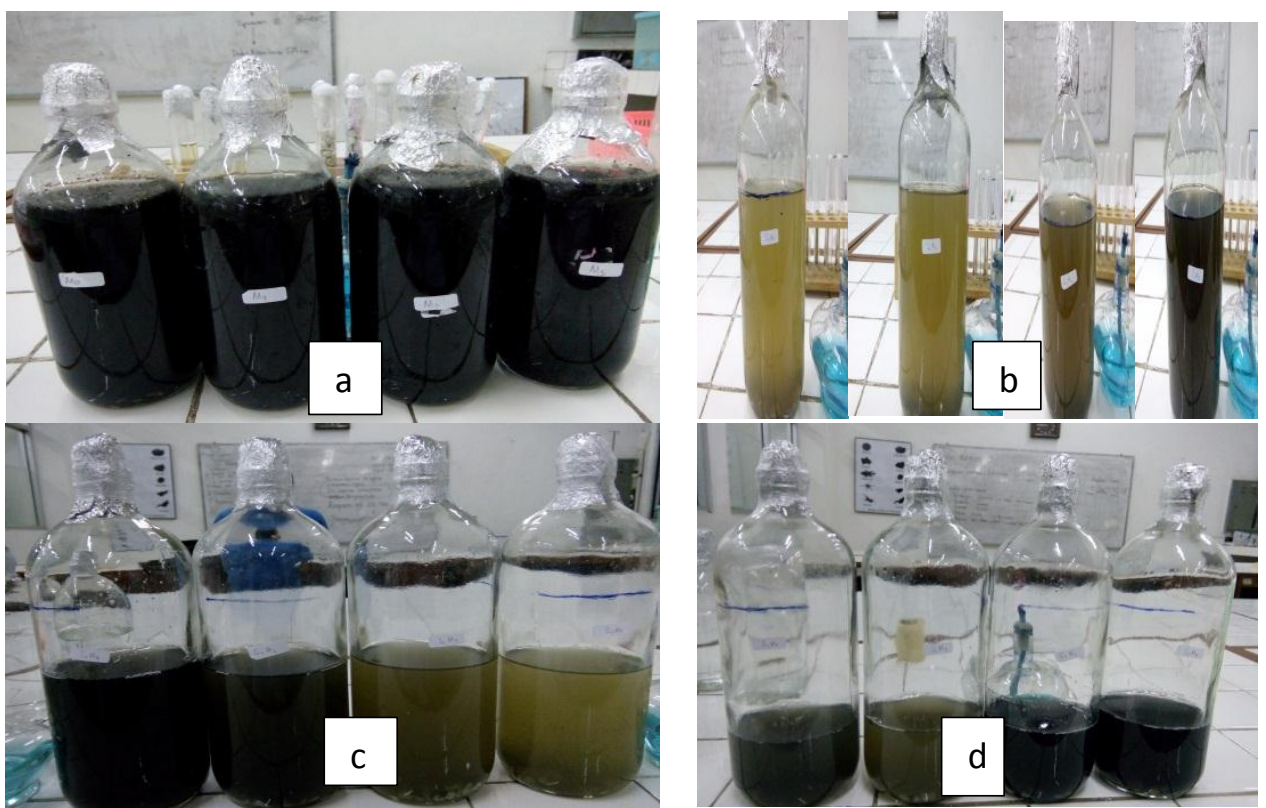

Gambar 1.Pertumbuhan konsorsium bakteri pereduksi sulfat secara batch culture (a) Stok konsorsium bakteri pereduksi sulfat umur 14 hari, (b) batch culture 0 hari, (c) batch culture umur 7 hari, batch culture umur 14 hari. 
Tyas Nyonita Punjungsari, 2017. Pengaruh Molase Terhadap Aktivitas Konsorsium Bakteri Pereduksi Sulfat Dalam Mereduksi Sulfat $\left(\mathrm{SO}_{4}^{-}\right)$. Journal Viabel Pertanian. (2017),11(2) 39-49

Tabel 2. Tabel konversi peningkatan warna pada masing batch culture dengan konsentrasi molase berbeda setiap periode waktu.

\begin{tabular}{cccccc}
\hline Konsentrasi molase & H0 & H1 & H3 & H7 & H14 \\
\hline 0 & + & + & + & +++ & ++++ \\
$308 \mathrm{mg} / \mathrm{L}$ & + & + & ++ & +++ & ++++ \\
$617 \mathrm{mg} / \mathrm{L}$ & ++ & ++ & +++ & ++++ & +++++ \\
$1.234 \mathrm{mg} / \mathrm{L}$ & +++ & +++ & ++++ & +++++ & ++++++ \\
\hline
\end{tabular}

Keterangan : (+) menunjukkan tingkatan warna hitam (gelap)

Selain perubahan warna indikator yang diamati adalah penurunan konsentrasi sulfat. Penurunan jumlah sulfat terlarut dalam media cair merupakan salah satu indikator adanya aktivitas bakteri pereduksi sulfat.

Berdasarkan grafik pada Gambar 2, diketahui penurunan sulfat paling cepat adalah pada konsentrasi molase $617 \mathrm{mg} / \mathrm{L}$ dan $1.234 \mathrm{mg} / \mathrm{L}$, namun pada konsentrasi tersebut mengakami kenaikan pada hari ke 14. Hasil ini bisa didapat karena pada batch culture tidak ada penambahan nutrient untuk kehidupan konsorsium, sehingga semakin lama nutrisi untuk memenuhi aktivitas metabolisme mikrobia semakin berkurang (tidak bisa membentuk atp dan tidak ada donor electron untuk aktivitas metabolism), sehingga mikrobia tidak mampu untuk melakukan reduksi sulfat.

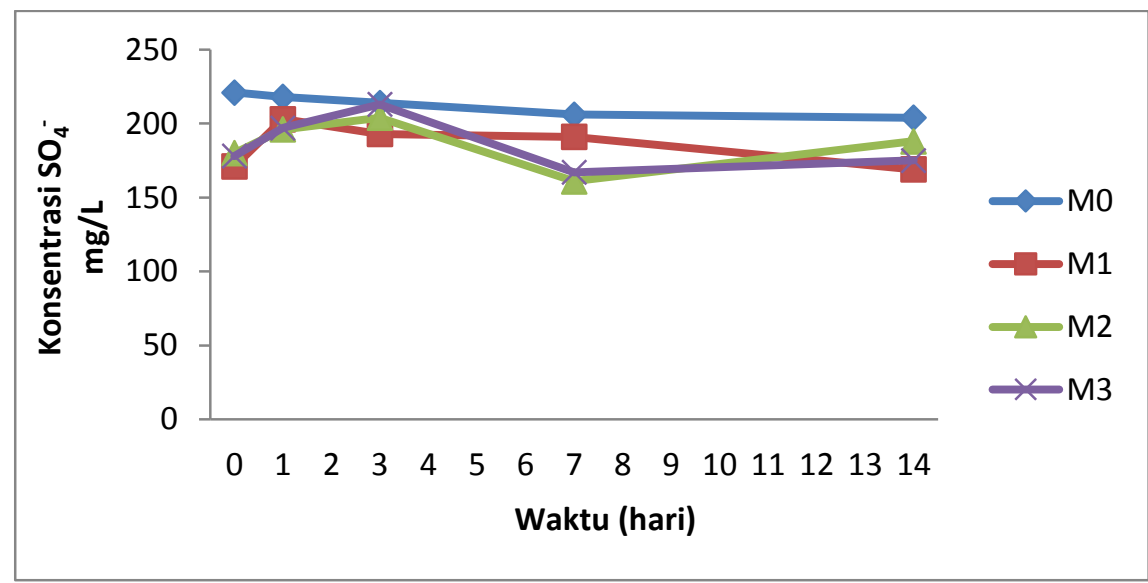

Gambar 2. Fluktuasi Sulfat selama waktu inkubasi 14 hari berdasarkan konsentrasi molase M0, M1, M2, M3.

Keterangan: $\mathrm{M} 0=$ Molase konsentrasi 0

M1 = Konsentrasi Molase $308 \mathrm{mg} / \mathrm{L}$

M2 $=$ Konsentrasi Molase $617 \mathrm{mg} / \mathrm{L}$

M3 = Konsentasi Molase $1.234 \mathrm{mg} / \mathrm{L}$

Hasil analisis secara statistik menunjukkan hasil yang sama dengan yang ditunjukkan oleh grafik karena didapatkan nilai significancy yang lebih kecil dari pada 0,05 . Sehingga dapat dinyatakan bahwa terdapat pengaruh penambahan molase terhadap penurunan kosentrasi sulfat oleh konsorsium bakeri pereduksi sulfat pada metode batch culture, Tabel 4. 
Tyas Nyonita Punjungsari, 2017. Pengaruh Molase Terhadap Aktivitas

Konsorsium Bakteri Pereduksi Sulfat Dalam Mereduksi Sulfat $\left(\mathrm{SO}_{4}^{-}\right)$. Journal Viabel Pertanian. (2017),11(2) 39-49

Tabel 4. Hasil analisis statistic hubungan konsentrasi molase dengan konsentrasi sulfat dalam batch culture menggunakan Anova.

\begin{tabular}{|l|c|r|r|r|r|}
\hline & $\begin{array}{c}\text { Sum of } \\
\text { Squares }\end{array}$ & df & Mean Square & F & Sig. \\
\hline Between Groups & 2707.750 & 3 & 902.583 & 4.035 & .026 \\
Within Groups & 3579.200 & 16 & 223.700 & & \\
Total & 6286.950 & 19 & & & \\
\hline
\end{tabular}

Letak perbedaannya ditunjukkan dengan menggunakan uji Duncan yang menghasilkan nilai significancy lebih kecil dari pada 0,05 pada konsentrasi molase 0 dengan konsentrasi molase $308 \mathrm{mg} / \mathrm{L}$, sehingga dinyatakan ada beda nyata antara konsentasi 0 dan konsentrasi $308 \mathrm{mg} / \mathrm{L}$. Hasil ini didapat karena berdasarkan grafik pada Gambar 5, konsentrasi molase $1.234 \mathrm{mg} / \mathrm{L}$ dan konsentrasi molase $617 \mathrm{mg} / \mathrm{L}$ mengalami kenaikan sulfat yang besarnya hampir sama dengan konsentrasi molase 0 pada hari ke 3, sehingga secara statistikpun menunjukkan tidak ada beda. Adapun menurut Bayoumy et al. (1998), jumlah sulfat per periode waktu seharusnya menurun karena sulfat yang ada pada batch culture digunakan BPS sebagai akseptor elektron terakirnya.

Hasil tersebut didukung oleh Widdel, et al. (2008) yang menyatakan bahwa bakteri pereduksi sulfat membutuhkan bahan organik yang cukup sebagai sumber karbon dan sumber energi untuk membentuk atp, yang nantinya berfungsi dalam proses pengendapan logam sesuai dengan reaksi 1 dan reaksi 2 . $\mathrm{CH} 2 \mathrm{O}$ merupakan sumber karbon sederhana. Karbon inorganik akan menetralisir $\mathrm{pH}$ dan membantu pengendapan mineral metal karbonat. Sulfida terlarut (H2S, HS-, dan S2-) bereaksi dengan logam membentuk metal sulfida yang mengendap (persamaan reaksi 4).

$$
\begin{gathered}
2 \mathrm{CH}_{2} \mathrm{O}+\mathrm{SO}_{4}{ }^{2-} \rightarrow \mathrm{S}^{2-}+2 \mathrm{CO}_{2}+2 \mathrm{H}_{2} \mathrm{O} \\
\text { BPS } \\
\mathrm{S}^{2-}+2 \mathrm{CO}_{2}+2 \mathrm{H}_{2} \mathrm{O} \rightarrow 2 \mathrm{HCO}_{3}{ }^{-}+\mathrm{H}_{2} \mathrm{~S} \\
\text { BPS } \\
\mathrm{H}_{5} \mathrm{~S}+\mathrm{M}^{2+} \rightarrow \mathrm{MS}+2 \mathrm{H}^{+} \\
\mathrm{M}^{2+}+2 \mathrm{H}_{2} \mathrm{O} \rightarrow \mathrm{M}(\mathrm{OH})_{2}(\mathrm{~s})+2 \mathrm{H}^{+}
\end{gathered}
$$




\section{KESIMPULAN}

Berdasarkan pada penelitian yang telah dilakukan maka didapatkan kesimpulan sebagai berikut:

1. Perubahan warna sudah terjadi sejak Hari ke 0 pada setiap konsentrasi molase menjadi kehitaman, menunjukan adanya aktivitas bakteri pereduksi sulfat pada kultivar yang digunakan.

2. Perubahan warna paling gelap pada periode waktu $0,1,3,7,14$ ditunjukkan oleh batch culture yang diberi molase dengan konsentrasi terbesar $(1.234 \mathrm{mg} / \mathrm{L})$.

3. Penurunan konsentrasi molase paling cepat terjadi pada batch culture dengan konsentrasi molase $617 \mathrm{mg} / \mathrm{L}$ dan $1.234 \mathrm{mg} / \mathrm{L}$.

4. Berdasarkan pengujian menggunakan Anova nilai significant yang diperoleh bernilai $0,026(<0,05)$ sehingga dinyatakan bahwa molase memberikan pengaruh yang signifikan terhadap aktifitas konsorsium bakteri pereduksi sulfat dalam mereduksi sulfat.

5. Berdasarkan uji lanjutan dengan menggunakan DMRT diketahui konsentrasi sulfat yang paling beda nyata adalah kontrol (konsentrasi molase $0 \mathrm{mg} / \mathrm{L}$ ) dan konsentrasi molase $308 \mathrm{mg} / \mathrm{L}$.

\section{DAFTAR PUSTAKA}

Bratkova, S., Koumanova, B., \& Beschkov, V. 2002. Biological treatment of mining wastewaters by fixed-bed bioreactors at high organic loading. Bioresour. Technol. 137, 409-413.

Cao, J., Zhang, G., Mao, Z., Li, Y., Fang, Z., \& Yang, C. 2012. Influence of electron donors on the growth and activity of sulfate-reducing bacteria. Int J Miner Process 106, 58-64.

Castro. 1993. Estudio de la melaza de ca na como sustrato de la fermentacion acetobutílica, Universidad Nacional de Colombia. Facultad de Ingeniería. Colombia.

Chen, Z.-F., Zhao, Y.-S., \& Li, Q. 2016. Influence of Fe(III) on Cr(VI) Reduction by Organic Reducing Substances from Sugarcane Molasses. Water Air Soil Pollut, 227: 19 DOI 10.1007/s11270-015-2678-X.

Detmers G., Alonso, R., Freire, S., Gonzáles-Álvarez, J., \& Antorrena, G. 2006. Uptake of phenol from aqueous solutions by adsorption in a Pinus pinaster bark packed bed. J. Hazard. Mater. B133, 61-67.

Fahruddin. 2010. Bioteknologi Lingkungan. Bandung: Alphabeta.

Havlin, J. B. 1999. Soil Fertility and Fertilizers. New Jersey. 528 p.: An Introduction to Nutrient Management. Prentice Hall.

Hesketh, A., Brooadhurst, J., \& Harrison, S. 2010. Mitigating the generation of acid mine drainage from copper sulphide tailings impoundments in perpetuity: a case study for an integrated management strategy. Miner. Eng.23 (3), 225-229.

Kleikemper, H., S. M., V., S. W., Schmucki, M., Bernasconi, S. M., \& Zeyer, J. 2002. Activity and Diversity of Sulfate-Reducing Bacteria in a Petroleum HydrocarbonContaminated Aquifer. Appl Environ Microbiol. doi:10.1128/AEM.68.4.15161523, 68(4): 1516-1523

Lens, P., Vallero, M., Esposito, G., \& Zandvoor, M. 1998. Perspectives of sulfate reducing bioreactors in environmental biotechnology. Sci. Biotechno, 311- 325. 
Liamleam, W., \& PAnnachhatre, A. 2007. Electron donors for biological sulphate reduction. Biotechnol. Adv. 25, 452-463.

Moncur, M. J. 2009. Mine drainage from the weathering of sulfide minerals and magnetite. Appl. Geochem, 24: 2362-2373.

Moodie, A., \& Ingledew, W. 1991. Microbial Anaerobic Respiration. Tempest, Advances in Microbial Physiology. Vol 31. USA: Academic Press Limited.

Moosa, S. N. 2002. A kinetic study of anaerobic reduction of sulphate: part I. Effect of Sulphate concentration. Chemical Engineering Science, 57: 2773- 2780.

Prescott, S. G and C. G. Dunn. 1959. "Industrial Microbiology". McGraw-Hill BookCompany, New York.

Purnamaningsih, N. 2016. Pengaruh Zeolit Alam Terhadap Aktivitas Konsorsium BPS Dalam Pengendapan Logam Mn. Tesis Pascasarjana Biologi UGM.

Rzecycka, M. and Blaszcyck. 2005. Growth and Activity of Sulphate-Reducing Bacteria in Media Containing Phosphogypsum and Different Sources of Carbon. Polish Journal of Environmental Studies, 14(6): 891-895.

Widdel, F. (1988). Microbiology and ecology of sulphate- and sulfur-reducing. A.J.B. (Ed.), 489-495. 